\title{
Ornamental potential of Schomburkgia crispa Lindl.
}

\author{
José Carlos Sorgato ${ }^{1 *}$ (D), Jackeline Schultz Soares ${ }^{1}$ (D), \\ Luan Marlon Ribeiro $^{1}$ (D), Anderson Giaretta Cabral $^{1}$ (D) \\ ${ }^{1}$ Universidade Federal da Grande Dourados, Faculdade de Ciências Agrárias, Dourados-MS, Brazil
}

\begin{abstract}
Orchids are one of the groups of plants with the greatest commercialization potential. They have floral characteristics highly valued in the sector of flowers and ornamental plants. However, exotics species are the most commercialized. The native species are still little explored for their ornamental potential. Thus, this work describes the vegetative and floral morphological characteristics of Schomburgkia crispa Lindl. aiming at evaluating its ornamental potential. For such, seven individuals were chosen. The quantitative characters were evaluated in all plants, totaling fifty pseudobulbs and eighty-eight flowers. During flowering, the most representative plant was chosen for the visual evaluation of its morphological features through photographs. A floral diagnosis sheet based on photos of fresh flowers was prepared by keeping the maximum level of morphological details. At the end of the experimental period, averages and standard deviations were calculated for each character evaluated. The species $S$. crispa presented, on average, plants $46.17 \mathrm{~cm}$ long, $31.50 \mathrm{~cm}$ wide, and with $88 \mathrm{~cm}$ of diameter. For flowering characters, the species presented in general 16.50 flowers per plant, 14.67 per flower stem, and 4.66 flowers opened per day, with an average durability of 32 days. Thus, we conclude that the species $S$. crispa has a great ornamental potential for use in ornamental horticulture.
\end{abstract}

Keywords: morphological features, native species, Orchidaceae, ornamental horticulture.

\section{Resumo}

Potencial ornamental de Schomburkgia crispa Lindl.

As orquídeas são um dos grupos de plantas com maior potencial de comercialização, por apresentarem características florais muito valorizadas no setor das flores e plantas ornamentais. Entretanto, as espécies mais comercializadas são exóticas e as nativas ainda são pouco exploradas quanto ao seu potencial ornamental. Assim, objetivou-se com este trabalho descrever aspectos morfológicos vegetativos e florais de Schomburgkia crispa Lindl., visando avaliar seu potencial ornamental. Para a avaliação do potencial ornamental da espécie, foram escolhidos sete indivíduos, dos quais os caracteres quantitativos foram avaliados em todas as plantas, totalizando cinquenta pseudobulbos e oitenta e oito flores. Durante a floração foi escolhida uma planta mais representativa para a realização de avaliação visual dos aspectos morfológicos da planta por meio de fotografias. Para retratar os aspectos morfológicos das flores foi elaborada uma ficha de diagnose floral, a partir de fotos das flores frescas, mantendo o máximo de detalhes morfológicos. Ao final do período experimental foram calculados as médias e o desvio padrão para cada um dos caracteres avaliados. A espécie S. crispa apresentou, em média, plantas com $46,17 \mathrm{~cm}$ de comprimento, $31,50 \mathrm{~cm}$ de largura e $88 \mathrm{~cm}$ de diâmetro. Quanto aos caracteres de florescimento, a espécie, de modo geral, apresentou 16,50 flores por planta, sendo 14,67 por haste floral e 4,66 flores abertas por dia, com durabilidade média de 32 dias. Sendo assim foi possível concluir que a espécie $S$. crispa apresenta elevado potencial ornamental para utilização na horticultura ornamental.

Palavras-chaves: aspectos morfológicos, espécies nativas, Orchidaceae, horticultura ornamental.

\section{Introduction}

State-of-the-art technologies incorporated into the production of flowers and ornamental plants have guaranteed a good performance of this sector in Brazil (Junqueira and Peetz, 2017a). In recent years, this segment has shown an annual growth between $6 \%$ and $9 \%$. In 2017 , it generated 6.9 billion reais along the production chain (Junqueira and Peetz, 2018).

The native ornamental flora should be considered as a germplasm bank for sustainable commercial exploitation, since it is desirable that these plants be used in breeding programs for the development of new cultivars such as Ionocidium Cerrado '101', Cattleya forbesii x Cattleya

*Corresponding author: jc_sorgato@hotmail.com 
bowringiana and Cattleya forbesii x Cattleya loddigesii (Cardoso, 2017; Colombo et al., 2017; Stulzer et al., 2019). Even with this possibility, native flora is virtually absent in commercial nurseries and in Brazilian flower shops, as well as information about supply of and demand for these species are incipient (Junqueira and Peetz, 2018; Zucchi et al., 2019).

Orchids are well known for their beauty and for other ornamental characteristics, such as their capacity of genetic combination and color diversity, shape, and durability of flowers (Zahara et al., 2017). Thus, producers have responded attentively to the continuous growth of this segment in the domestic market. Each year they introduce new hybrids of orchids resulting from improvements. There are currently registered 2,345 cultivars of orchids (Junqueira and Peetz, 2017b).

This botanical family is representative in the plant biodiversity of the Cerrado biome (Flora do Brasil forthcoming, 2020). This biome has little-explored species for economic, pharmacological, medicinal, and ornamental purposes (Belloto et al., 2017; Soares et al., 2020). Thus, native species with possible ornamental potential should be studied, given the high demand for plants to supply the market of flower and ornamental plants.

Moreover, the insertion of native orchids in the market can minimize illegal and irrational extraction from nature, besides reducing losses in biodiversity (Gale et al., 2018; Junqueira and Peetz, 2018). Schomburgkia crispa Lindl. is among the native orchids that can have great ornamental potential. This plant occurs in riverside forests and dry forests of the Cerrado (Ostetto, 2015; Barros et al., 2018).

Prospecting the potential of native species of orchids as ornamental plants may be an opportunity for Brazil to produce, commercialize and obtain self-sufficiency in the production of cultivars and seedlings (Cardoso, 2013) even for small producers, as it contributes to the preservation of local flora and highlights regional identities (Junqueira and Peetz, 2018). Thus, this work describes vegetative and floral morphological characteristics of Schomburgkia crispa Lindl. aiming at evaluating its ornamental potential.

\section{Materials and Methods}

This study was carried out using $S$. crispa plants aged 12 from the Várzeas do Rio Ivinhema - MS State Park (22 $\left.57^{\prime} 33.2^{\prime \prime} \mathrm{S} ; 53^{\circ} 40^{\prime} 06.5^{\prime} \mathrm{W}\right)$ and allocated in a screened nursery (photosynthetically active radiation $(\mathrm{PAR})=235.1$ $\mu \mathrm{mol} \mathrm{m} \mathrm{m}^{-2} \mathrm{~s}^{-1}$ ) located in the Orchidarium of the School of Agricultural Sciences (FCA/UFGD) (22 $111^{\prime} 53.2^{\prime \prime} \mathrm{S}$; $\left.54^{\circ} 56^{\prime} 02.3^{\prime \prime} \mathrm{W}\right)$. The study was conducted from May to June 2018 and from May to June 2019.

According to the Köppen classification, the region's climate is Am (Tropical Monsoon) with hot summers and dry winters. The maximum temperatures occur in December and January $\left(31.7^{\circ} \mathrm{C}\right)$ and the minimum temperatures are between May and August $\left(19.5^{\circ} \mathrm{C}\right)$, coinciding with excess rainfalls in spring-summer and water deficit in autumnwinter (Fietz et al., 2017).

For the evaluation of the ornamental potential of this species seven individuals were chosen. The quantitative characters were evaluated in all plants in two flowering seasons (2018 and 2019), totaling fifty pseudobulbs, one hundred leaves, seven inflorescences and approximately eighty-eight flowers per flowering.

The vegetative morphological characteristics evaluated were as follows: length, width and circumference of the plant - measured in each pot separately; number, length (measured from its insertion in the pseudobulb to the apex of the leaf blade) and width of the median portion of the leaf (measured from its most expanded transversal portion). Measures were also taken for the number, length (measured from its insertion in the rhizome until the beginning of leaf insertion) and the diameter of pseudobulbs (measured from the most expanded transversal portion).

Measures for floral morphological characteristics included the number and length (measured from the insertion of the stem in the pseudobulb to the first flower) of flower stems; length (measured from the insertion of the first flower to the apex of inflorescence), diameter (obtained by the longest distance between two opposite flowers) and number of flowers of the inflorescence; in addition to the number of flowers opened per inflorescence per day. These characteristics were obtained in fully developed inflorescences and in full bloom. The average length of the bracteole was measured from the insertion of the floral stem to the apex of that structure. The durability of inflorescences and flowers was recorded daily while they remained on the plant, which were previously labeled and followed from anthesis to senescence (they were characterized as senescent flowers that presented petals and murky sepals, with darkening and loss of natural brightness).

During flowering, the most representative individual was chosen for a visual evaluation of its morphological features through photographs. A floral diagnosis sheet based on photos of fresh flowers was also prepared by keeping the maximum level of morphological details. At the end of the experimental period, means and standard deviations were calculated for each quantitative character evaluated.

\section{Results and Discussion}

The species $S$. crispa presented, on average, plants $46.77 \mathrm{~cm}$ long, $27.92 \mathrm{~cm}$ of diameter, and with 75.31 $\mathrm{cm}$ of circumference. Each individual presented about 8 pseudobulbs $(25.00 \mathrm{~cm}$ of length and $2.99 \mathrm{~cm}$ of diameter) and 16 leaves $(23.00 \mathrm{~cm}$ of length and $4.78 \mathrm{~cm}$ wide in the median portion). On average, there were one to two floral stems $(84.50 \mathrm{~cm})$ per plant. Inflorescences were $12.35 \mathrm{~cm}$ long and $14.09 \mathrm{~cm}$ in diameter and had an average bracteole length of $4.87 \mathrm{~cm}$ (Table 1). 
Table 1. Mean values of vegetative and floral morphological characteristics of Schomburgkia crispa Lindl. mean values (MV) and standard deviation (SD).

\begin{tabular}{|c|c|c|c|}
\hline \multirow{2}{*}{ Morphological characteristics } & 2018 & 2019 & \multirow{2}{*}{$\begin{array}{c}\text { General Mean } \\
\qquad \mathrm{MV} \pm \mathrm{SD}\end{array}$} \\
\hline & \multicolumn{2}{|c|}{ 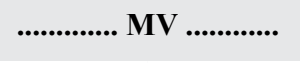 } & \\
\hline Length of plant (cm) & 46.17 & 47.29 & $46.77 \pm 8.11$ \\
\hline Diameter of plant $(\mathrm{cm})$ & 31.50 & 24.86 & $27.92 \pm 7.48$ \\
\hline Circumference of plant (cm) & 88.00 & 64.43 & $75.31 \pm 34.48$ \\
\hline Number of pseudobulb per plant & 8.33 & 8.29 & $8.31 \pm 1.60$ \\
\hline Length of pseudobulb (cm) & 26.00 & 24.14 & $25.00 \pm 5.34$ \\
\hline Diameter of pseudobulb (cm) & 2.60 & 3.00 & $2.99 \pm 0.99$ \\
\hline Number of leaves per plant & 16.50 & 16.57 & $16.54 \pm 3.07$ \\
\hline Length of leaves $(\mathrm{cm})$ & 23.17 & 22.86 & $23.00 \pm 3.61$ \\
\hline Wide in the median portion of leaves $(\mathrm{cm})$ & 4.79 & 4.77 & $4.78 \pm 0.78$ \\
\hline Number of floral stems per plant & 1.00 & 1.14 & $1.08 \pm 0.28$ \\
\hline Length of inflorescence (cm) & 14.33 & 10.64 & $12.35 \pm 4.20$ \\
\hline Diameter of inflorescence $(\mathrm{cm})$ & 14.67 & 13.60 & $14.09 \pm 2.53$ \\
\hline Average bracteole length $(\mathrm{cm})$ & 4.67 & 5.05 & $4.87 \pm 1.16$ \\
\hline Floral stem length $(\mathrm{cm})$ & 84.17 & 84.79 & $84.50 \pm 24.20$ \\
\hline Number of flowers of the inflorescence & 14.67 & 11.36 & $12.96 \pm 4.25$ \\
\hline Number of flowers opened by inflorescence per day & 4.66 & 3.56 & $4.14 \pm 0.65$ \\
\hline Durability of inflorescence (days) & 32.50 & 30.07 & $31.19 \pm 5.41$ \\
\hline Durability of flowers (days) & 32.67 & 25.86 & $29.00 \pm 5.96$ \\
\hline
\end{tabular}

These results corroborate the findings of Flora do Brasil forthcoming (2020) and those of Koch and Silva (2012) in the book "Orchids native to Mato Grosso". They reported that this species has characteristics such as fusiform, furrowed, and bifoliate pseudobulbs, leaves from 24 to 26 $\mathrm{cm}$ in length and 5 to $7 \mathrm{~cm}$ wide, inflorescences of 95 to 110 $\mathrm{cm}$ on average, and brown petals and sepals with yellow and crinkled margins.

The length of plant, pseudobulbs, and leaves of S. crispa are appropriate characteristics to be used as potted plants, cut flowers, and for landscaping (Figure 1). In ornamental horticulture, the study of these characteristics is important for cultivation, mainly commercial cultivation. They can define the spacing between plants, pot length, and crop management (Hunhoff et al., 2016). In addition, epiphytes can be widely used in vertical gardens. Species with apparent aerial roots, robust leaves, pseudobulbs, and long and exuberant floral stems are often asked for by landscape professionals to compose such spaces. All these factors occur in S. crispa, highlighting its potential as ornamental plant. 


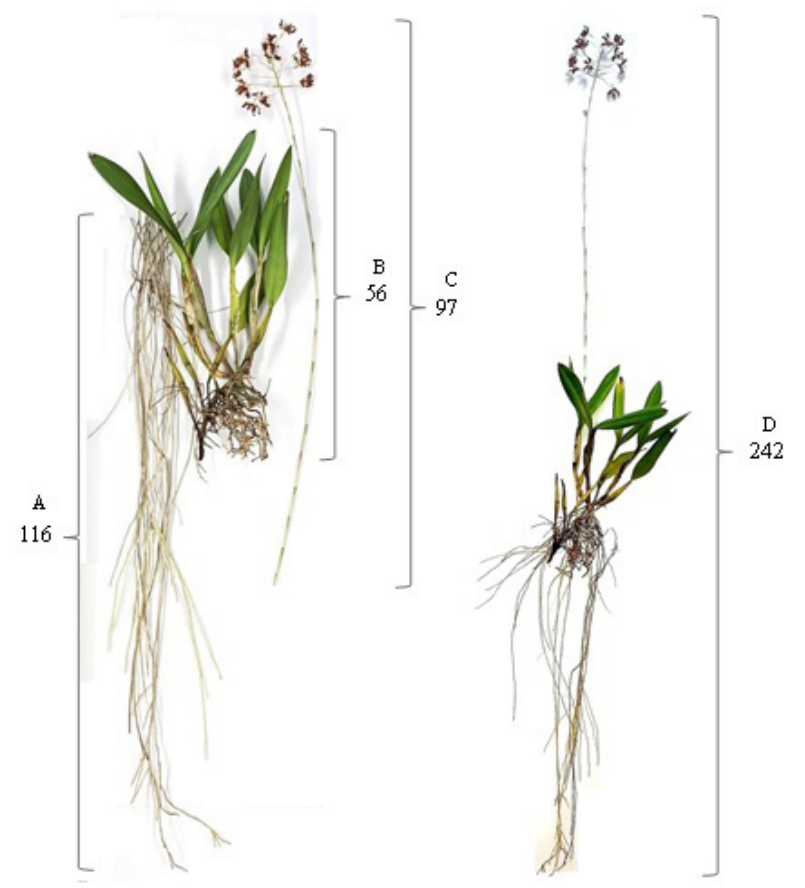

Figure 1. General morphological aspects of Schomburgkia crispa Lindl. Values are expressed in centimeters (cm). $\mathrm{A}=$ root system; $\mathrm{B}=$ shoots (rhizome, pseudobulb, and leaf) $\mathrm{C}=$ floral stem and inflorescence; $\mathrm{D}=$ whole plant.

As for flowering characters, in general this species presented 12.96 flowers per flower stem and 4.14 flowers opened per day. The flowering period of S. crispa started in the last half of May and ended in the first half of June both in 2018 and 2019. Each inflorescence lasted, on average, 31.19 days, and each flower lasted 29.00 days (Table 1).

The flowers of $S$. crispa are considered to have great durability, since other native species, such as Cattleya lundii Rchb. f. \& Warm., C. bowringiana O'brien and Oncidium pumillum Lindl., have flowers that last between ten and 15 days, and 15 days and ten days, respectively (Cardoso and Israel, 2005; Colombo et al., 2017).

Some aspects are important for the choice of plants for landscaping, such as inflorescences that stand out, flowers with a long flowering period, and the maintenance of these aspects for more than 30 days (Pinheiro et al., 2012; Hunhoff et al., 2016).

When analyzing the aspects of the flower morphology of $S$. crispa, the flowers have sepals and petals with an average of $21 \mathrm{~mm}$ and a labellum of $17.55 \mathrm{~mm}$. The flower length is about $33 \mathrm{~mm}$ and its width are $45 \mathrm{~mm}$ (Figure 2). 


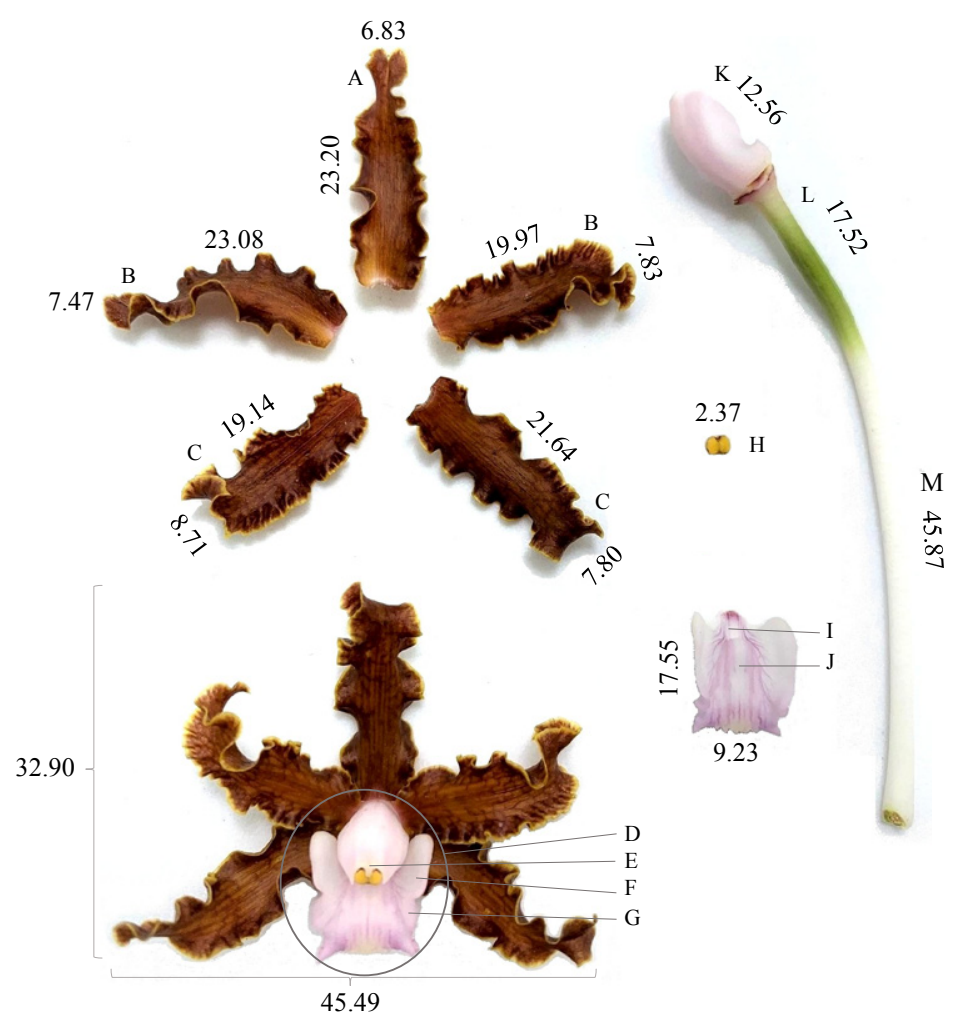

Figure 2. Floral diagnosis sheet made using images of fresh flowers of Schomburgkia crispa Lindl. Values are expressed in millimeters $(\mathrm{mm})$. A = dorsal sepal; $\mathrm{B}=$ lateral petals; $\mathrm{C}=$ lateral sepals; $\mathrm{D}=$ labellum (median petal);

$\mathrm{E}=$ anther; $\mathrm{F}=$ lateral lobe of the labellum; $\mathrm{G}=$ median lobe of the labellum; $\mathrm{H}=$ pollinous; $\mathrm{I}=$ operculum; $\mathrm{J}=$ labellum; $\mathrm{K}=$ column; $\mathrm{L}=$ ovary; $\mathrm{M}=$ pedicel.

The visual effects ornamental plants can produce are associated with the groups or types they belong to (trees, shrubs, climbing plants, herbs etc.) and with the particular attributes of each plant, such as the effect of flowers or showy foliage (Antônio, 2013). The results of flowering characteristics obtained for $S$. crispa, associated with its floral characteristics, suggest that the length and durability of inflorescence and flowers, combined with color, length and number of flowers produced per inflorescence, are ornamental characteristics that provide a greater attractiveness and that can be used in the sector of ornamental horticulture and landscaping (Hunhoff et al., 2016).

In landscaping, since the Brazilian Colonial period, influenced by the European style of gardening, numerous exotic species were introduced due to the lack of information on the use of native species in landscaping projects (Leal and Biondi, 2006; Paiva, 2008). Most of the time, the ornamental value of native plants is only recognized when they are studied and improved by other countries. Several species are suitable for landscaping, but there is exhaustive repetition of plants already consecrated and accepted by the population, many of which are unsuitable for the place where they are used (Leal and Biondi, 2006). Thus, native species are still little representative in the flower and ornamental plants market compared to the existing diversity in Brazil. Therefore, they should be further studied and introduced in the Brazilian market.

\section{Conclusions}

According to the results obtained for S. crispa, the vegetative characteristics, such as apparent aerial roots, long and robust leaves and pseudobulbs, in addition to long and exuberant floral stems, emphasize its potential as ornamental plant. In addition, it can be suggested that the length and durability of inflorescence and flowers, combined with color, size and number of flowers produced by inflorescence, are ornamental features that play a significant role in providing greater attractiveness. They can be used in the ornamental horticulture sector, reinforcing and stimulating the use of native Cerrado species in landscaping projects.

\section{Author Contribution}

JCS: planning, experimental execution and evaluation, interpretation and discussion of results and writing; JSS: planning, experimental execution, literature review and writing; LMR: planning and experimental execution and evaluation and AGC: planning, statistical analysis and writing correction. 


\section{References}

ANTÔNIO, M.T.B. Paisagismo produtivo. Ornamental Horticulture, v.19, n.1, p.47-54, 2013.

BARROS, F.; HALL, C.F.; PAIVA NETO, V.B.; BATISTA, J.A.N. Checklist das Orchidaceae do estado do Mato Grosso do Sul, Brasil. Iheringia Série Botânica, v.73, n.supl., p.287-296, 2018. https://doi.org/10.21826/2446$8231201873 \mathrm{~s} 287$

BELLOTO, C.A.; SOUZA, G.K.; PERIN, P.C.; SCHUQUEL, I.T.A.; SANTIN, S.M.O.; CHIAVELLI, L.U.R.; GARCIA, F.P.; KAPLUM, V.; RODRIGUES, J.H.S.; SCARIOT, D.B.; DELVECCHIO, R.; MACHADOFERREIRA， E.; AGUIAR, R.S.; SOARES， C.A.G.; NAKAMURA, C.V.; POMINI, A.M. Crispoic acid, a new compound from Laelia marginata (Orchidaceae), and biological evaluations against parasites, human cancer cell lines and Zika virus. Natural Product Research, v.32, n.24, p.1-6, 2017. https://doi.org/10.1080/14786419.2017 .1395428

CARDOSO, J.C. Melhoramento de espécies ornamentais como estratégia para o desenvolvimento e autossuficiência do setor. Revista Brasileira de Horticultura Ornamental, v.31, n.1, p.171-171, 2013. https://doi.org/10.1590/S010205362013000100028

CARDOSO, J.C. Ionocidium 'Cerrado 101': intergeneric orchid hybrid with high quality of blooming. Ornamental Horticulture, v.23, n.3, p.351-356, 2017. https://doi. org/10.14295/oh.v23i3.1110.

CARDOSO, J.C.; ISRAEL, M. Levantamento de espécies da família Orchidaceae em Águas de Sta. Bárbara (SP) e seu cultivo. Revista Brasileira de Horticultura Ornamental, v.23, n.2, p.169-173, 2005. http://dx.doi.org/10.1590/ S0102-05362005000200001.

COLOMBO, R.C.; HOSHINO, R.T.; FERRARI, E.A.P.; ALVES, G.A.C.; FARIA, R.T.D. Cattleya forbesii x Cattleya bowringiana: a new hybrid of Cattleya orchid. Crop Breeding and Applied Biotechnology, v.17, n.2, p.184-186, 2017. https://doi.org/10.1590/1984$70332017 \mathrm{v} 17 \mathrm{n} 2 \mathrm{c} 28$

FIETZ, C.R.; FISCH, G.F.; COMUNELLO, E.; FLUMIGNAN, D.L. O clima da região de Dourados, MS. Dourados: Embrapa Agropecuária Oeste, 2017. 138.

FLORA DO BRASIL FORTHCOMING. 2020. Jardim Botânico do Rio de Janeiro. Available at: <http:// floradobrasil.jbrj.gov.br/>. Accessed on: Nov 03, 2020.
GALE, S.W.; FISCHER, G.A.; CRIBB, P.J.; FAY, M.F. Orchid conservation: bridging the gap between science and practice. Botanical Journal of the Linnean Society, v.186, n.4, p.425-434, 2018. https://doi.org/10.1093/ botlinnean/boy003.

HUNHOFF, V.L.; SILVA, C.A.; LAGE, L.A.; KRAUSE, W.K.; PALU, E.G. Biologia, morfologia floral e potencial ornamental de Cyrtopodium saintlegerianum (Orchidaceae). Revista Agroambiente On-line, v.10, n.4, p.358-363, 2016. http://dx.doi.org/10.18227/19828470ragro.v10i4.3925.

JUNQUEIRA, A.H.; PEETZ, M.S. Brazilian consumption of flowers and ornamental plants: habits, practices and trends. Revista Brasileira de Horticultura Ornamental, v.23, n.2, p.178-184, 2017a. https://doi.org/10.14295/ oh.v23i2.1070.

JUNQUEIRA, A.H.; PEETZ, M.S. Intellectual property rights in Brazilian floriculture: innovations for the growth and development of the market. Revista Brasileira de Horticultura Ornamental, v.23, n.3, p.296-306, 2017 b. https://doi.org/10.14295/oh.v23i3.1071.

JUNQUEIRA, A.H.; PEETZ, M.S. Sustainability in Brazilian floriculture: introductory notes to a systemic approach. Revista Brasileira de Horticultura Ornamental, v.24, n.2, p.155-162, 2018. https://doi. org/10.14295/oh.v24i2.1253.

KOCH, A.K.; SILVA, C.A. Orquídeas nativas de Mato Grosso. Cuiabá: Editora Carlini \& Caniato, 2012. 112p.

LEAL, L.; BIONDI, D. Potencial ornamental de espécies nativas. Revista Científica Eletrônica de Engenharia Florestal, v.4, n.8, p.1-16, 2006.

OSTETTO, S. Orquídeas de Mato Grosso do Sul. Campo Grande: Alvorada, 2015. 141p. vol.1.

PAIVA, P.D.O. Paisagismo: conceitos e aplicações. Lavras: Editora UFLA, 2008. 608p. vol.1.

PINHEIRO, P.G.L.; LEITE, K.P.; LIRA JUNIOR, M.L.; LOGES, V.; CASTRO, M.F.A. Heliconia characteristics for landscape use. Acta Horticulturae, v.953, n.1, p.293298, 2012. http://10.17660/ActaHortic.2012.953.40

STULZER, G.C.G.; HOSHINO, R.T.; SUZUKI, A.B.P.; PAULA, J.C.B.D.; ALVES, G.A.C.; FARIA, R.T.D. Primary hybrid of Cattleya forbesii x Cattleya loddigesii, a new brazilian orchid. Crop Breeding and Applied Biotechnology, v.19, n.3, p.364-367, 2019. https://doi. org/10.1590/1984-70332019v19n3c50. 
SOARES, J.S.; SANTIAGO, E.F.; SORGATO, J.C. ZUCCHI, M.R. Ornamental and landscape potential Conservation of Schomburgkia crispa Lindl. (Orchidaceae) of a bromeliad native to the Cerrado. Ornamental by reintroduction into a fragment of the Brazilian Cerrado. Horticulture, v.25, n.4, p.425-433, 2019. https://doi. Journal for Nature Conservation, v.53, p.125754, 2020. $\quad$ org/10.1590/2447-536x.v25i4.2003. https://doi.org/10.1016/j.jnc.2019.125754.

ZAHARA, M.; DATTA, A.; BOONKORKAEW, P.; MISHRA, A. The effects of different media, sucrose concentrations and natural additives on plantlet growth of Phalaenopsis Hybrid 'pink'. Brazilian Archives of Biology and Technology, v.60, n.1, p.01-15, 2017. http://10.1590/1678-4324-2017160149 